\title{
Studi Kemampuan Transfer Daya Maksimum Dengan Kendala Stabilitas Tegangan Pada Interkoneksi Sumbagsel
}

\author{
Jaka Wibowo, Lukmanul Hakim, Endah Komalasari \\ Jurusan Teknik Elektro Universitas Lampung \\ Jl. Prof. Sumantri Brojonegoro No. 1 Bandar Lampung 35145 \\ jakawibowoelektro6unila@gmail.com
}

\begin{abstract}
Abstrak
Suatu sistem interkoneksi memungkinkan suatu wilayah yang kekurangan energi listrik akan dapat terpenuhi kebutuhannya dari pasokan energi listrik yang dikirimkan oleh wilayah dengan daya pembangkitan berlebih. Pengiriman daya pada sistem interkoneksi secara kontinu dengan baik memerlukan suatu sistem yang handal. Proses transfer daya antar wilayah pada sistem interkoneksi agar dapat terpenuhi dengan baik maka memerlukan suatu perencanaan dan studi tentang pengaruh perubahan beban pada sistem dengan tetap menjaga batas toleransi nilai tegangan dalam kondisi yang masih diizinkan dalam pengiriman daya.

Metode yang digunakan untuk menyelesaikan aliran daya pada tugas akhir ini menggunakan solusi Continuation Power Flow (CPF) pada toolbox PSAT 2.1.6 Matlab dengan langkah prediksi dan koreksi untuk kenaikan $\lambda$ (faktor pengali kenaikan beban). Untuk skenario simulasi program, dipilih dengan menambahkan beban sebesar per10 MW di setiap beban baik saat luar waktu beban puncak (LWBP) maupun saat waktu beban puncak (WBP) pada sistem Lampung. Transfer daya maksimum saat LWBP dan WBP terjadi pada penambahan beban sebesar 140 MW dengan nilai daya terbesar terdapat pada saluran yang menghubungkan Baturaja-Bukit Kemuning (5153) sebesar 336,6633 MW (LWBP) dan 324,4741 MW (WBP).
\end{abstract}

Kata kunci : Interkoneksi, Transfer daya, Continuation Power Flow (CPF)

\begin{abstract}
An interconnection system allows a region with lack of electricity supplied by the region with excess power. Power distribution on continue interconnection system in good condition requires a reliable system. The process of power transfer between regions in order to interconnect the system met with both the planning and requires a study of the effect of changes in the load on the system while maintaining the tolerance limit voltage value in a condition that is still allowed in the delivery of power.

The method used to solve power flow in this paper using the solution from Continuation Power Flow (CPF) on PSAT 2.1.6 Matlab toolbox with prediction and correction steps to determine the increase in $\lambda$ (multiplier factor increase in load). For the scenario simulation program, adding a load of $10 \mathrm{MW}$ in each load at beyond the time when the peak load (Luar Waktu Beban Puncak/LWBP) or during peak load time (Waktu Beban Puncak/WBP) in Lampung system. Maximum power transfer occurs when LWBP and WBP on additional load of 140 MW with the largest value of the power contained in the channel that connects Baturaja-Bukit Kemuning (51-53) of 336.6633 MW (LWBP) and 324.4741 MW (WBP).
\end{abstract}

Key word : interconnection, power transfer, Continuation Power Flow (CPF)

\section{PENDAhUluan}

Sistem tenaga listrik harus selalu dijaga dalam keadaan yang baik, maka dibutuhkan suatu sistem yang handal dalam memberikan pelayanan distribusi listrik. Pertumbuhan beban suatu wilayah akan cenderung lebih pesat dibandingkan pertambahan pembangkit pada wilayah tersebut. Hal ini dapat mengakibatkan pemenuhan kebutuhan energi listrik pada suatu wilayah tidak dapat terpenuhi dengan baik. Sedangkan pemenuhan kebutuhan masyarakat akan listrik dewasa ini terbilang sangat meningkat. Berdasarkan data PLN Lampung tahun 2011, untuk wilayah Lampung pertumbuhan listrik ratarata mencapai $50 \mathrm{MW}-60 \mathrm{MW}$ atau $12 \%$ per tahun [1]. Dengan peningkatan kebutuhan beban tersebut maka sangat penting untuk menjaga 
keseimbangan antara penyediaan pasokan listrik dengan pertumbuhan konsumsi listrik masyarakat atau neraca daya dan economic dispatch yang juga berpengaruh besar terhadap peningkatan taraf ekonomi suatu bangsa. Suatu sistem interkoneksi merupakan solusi yang pantas untuk menyelesaikan permasalahan kebutuhan energi listrik, karena dengan sistem interkoneksi memungkinkan suatu wilayah yang kekurangan asupan energi listrik akan dapat terpenuhi kebutuhannya dari pasokan energi listrik yang dikirimkan oleh wilayah yang memiliki daya yang berlebih. Pada Sistem Interkoneksi Sumbagsel, wilayah Sumatera Selatan bertindak sebagai wilayah yang kelebihan daya atau area pengirim sedangkan Lampung sebagai area terima.

Hal yang dipertimbangkan dari transfer daya pada sistem interkoneksi adalah kestabilan tegangan pada bus yang terhubung antara dua area dan saluran yang menghubungkan antara bus-bus tersebut. Pada Sistem Interkoneksi Sumbagsel, bus yang menghubungkan antara wilayah Sumatera Selatan dan Lampung antara lain adalah bus GI Bukit Asam, GI Baturaja, GI Blambangan Umpu, GI Bukit Kemuning, dan GI Kotabumi. Saluran yang menghubungkan antara dua wilayah ini adalah saluran Baturaja-Bukit Kemuning dan Baturaja-Blambangan Umpu. Permasalahan transfer daya dapat diselesaikan dengan studi aliran daya pada sistem tenaga listrik, kemudian langkah yang perlu dilakukan adalah memprediksi sejauh mana kenaikan beban pada area Lampung sehingga didapatkan nilai pembebanan maksimum yang juga masih dalam batas kestabilan tegangan dalam proses pengiriman daya. Metode yang digunakan adalah dengan prediksi dan koreksi CPF (Continuation Power Flow) untuk penyelesaian aliran daya.

\section{TINJAUAN PUSTAKA}

\subsection{Penelitian Terdahulu}

Penyelesaian aliran daya dengan metode Continuation Power Flow (CPF) merupakan cara yang baik untuk menghasilkan kurva P-V , Q-V atau P-Q-V dalam menentukan perilaku sebuah sistem tenaga listrik dengan mensetting variasi injeksi daya. Kurva P-V dihasilkan dengan menginjeksikan tegangan dan daya aktif yang telah ditentukan, sedangkan daya reaktif nya variable. Pada kurva Q-V daya aktif dan daya reaktif beban telah diketahui.
Secara umum variasi injeksi daya yang terjadi pada sistem tenaga adalah nonlinear. Sebuah penelitian dengan model pendekatan piecewiselinear yang dimasukkan kedalam variasi beban nonlinear dan menggabungkannya kedalam continuation power flow [2]. Hal ini akan menunjukkan keseragaman variasi pada injeksi daya dan variasi nonlinear yang berbeda dari kurva P-V. Dalam penelitian ini mengilustrasikan tiga kasus dalam memvariasikan perubahan beban. Model sistem yang digunakan adalah tiga bus sistem; bus 1 merupakan slack bus, bus 2 adalah PV bus dan bus 3 adalah PQ bus dengan bus beban PQ2 pada bus 2 dan PQ3 pada bus 3 . Kasus pertama menambahkan beban secara linear, kasus yang kedua mengubah beban nonlinear pada PQ2 dan kasus yang ketiga mengubah nonlinear beban pada PQ2 dan PQ3. Dari penelitian ini menunjukkan bahwa variasi injeksi daya mempengaruhi margin beban tiap kurva P-V, P-Q maupun P-V-Q yang sesuai, dan juga perbedaan antara variasi injeksi linear dan nonlinear sangat signifikan.

Sangatlah penting untuk mempertimbangkan stabilitas transien dengan kontrol korektif pelepasan generator dan pelepasan beban sebagai langkah sistem proteksi sebuah sistem[3]. Metode ini didasarkan pada metode interior point Newton untuk pemrograman nonlinier dan pendekatan kemampuan transfer sebagai maksimalisasi transfer daya antara kendala statis dan dinamis yang digabungkan ke dalam sebuah formulasi Transient Stability Constrained Optimal Power Flow (TSCOPF). Pemilihan generator dan beban yang dilepas didasarkan pada nilai masing-masing Lagrange multipliers untuk stabilitas sudut rotor generator dan persamaan active power balance. Dengan demikian alangkah baiknya untuk melakukan studi transfer daya maksimum dengan kendala stabilitas lainnya (stabilitas dinamik, stabilitas steady state) dan dengan sistem yang lebih luas demi melihat pengaruh transfer daya maksimum pada sistem tenaga.

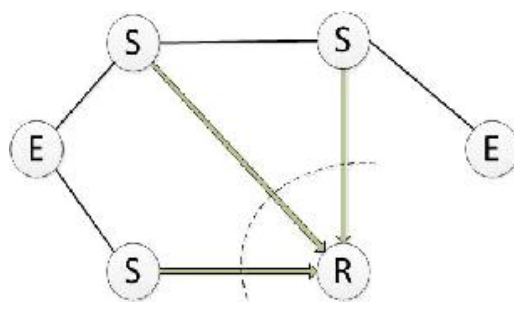

Gambar 2.1 Sistem interkoneksi sederhana sistem tenaga 
Pada gambar 2.1 menunjukkan sebuah sistem sederhana dari interkoneksi yang terdiri dari beberapa area yaitu:

$(\mathrm{S})$ = area pengirim --------- = wilayah transfer daya
$(\mathrm{R})=$ area penerima
$(E)=$ area eksternal

\subsection{Transfer Capability}

Transfer Capability didefinisikan sebagai ukuran dari kemampuan sistem interkoneksi dalam hal keandalan transfer daya dari satu area ke area yang lain dengan semua jalur transmisi dibawah kondisi tertentu (sebelum dan sesudah kontingensi). Sedangkan Total Transfer Capability (TTC) merupakan jumlah energi listrik yang dapat dikirimkan melalui jaringan transmisi secara handal yang memenuhi semua hal yang dipertimbangkan sebelum dan sesudah kontingensi kondisi sistem [4]. Hal-hal yang perlu dipertimbangkan tersebut adalah:

\section{a. Thermal loading}

Thermal loading yaitu jumlah maksimum energi listrik yang dapat dikirimkan pada saluran transmisi tanpa menyebabkan panas

\section{b. Voltage problem}

Voltage problem yaitu tegangan sistem dan perubahan tegangan yang harus dijaga dengan kisaran tertentu.

\section{c. Angular Stability (stabilitas sudut)}

Angular Stability yaitu stabilitas sistem transmisi yang mampu bertahan terhadap gangguan pada periode transien dan dinamis.

Dengan demikian, kondisi sistem yang berubahubah akibat adanya thermal loading, voltage problem, dan angular stability dapat di ilustrasikan dengan gambar 2.2. Total transfer daya yang dapat dikirimkan dari area kirim ke area terima ditunjukkan dari batas stabilitas sistem yang memperhitungkan batas suhu penghantar (garis putus-putus biru), stabilitas sudut (garis hijau), dan batas tegangan (garis merah). Batas suhu penghantar dari sebuah sistem memiliki titik optimum sehingga pada grafik dibuat stabil dengan garis putus-putus biru. Batas tegangan dan stabilitas sudut suatu sistem pada saat terjadi gangguan terlihat pada garis merah dan hijau yang transien sehingga perlu dikembalikan pada kondisi stabil. Total transfer daya yang dapat terpenuhi berada dibawah kondisi batas tegangan dan suhu yang stabil.

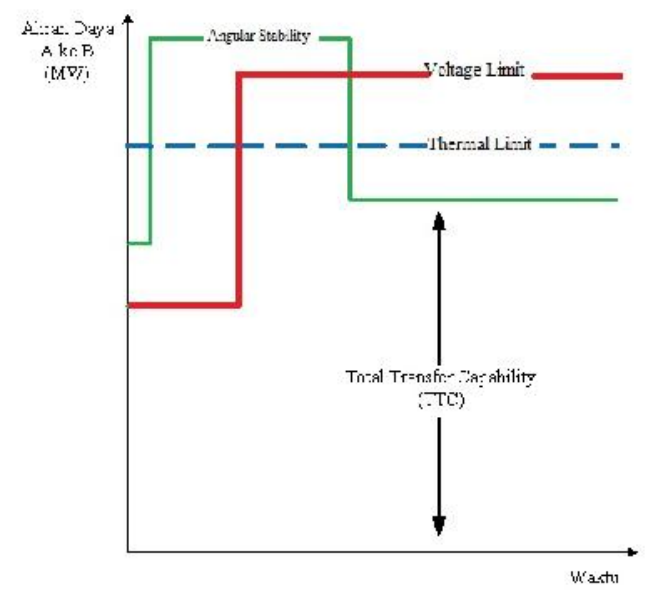

Gambar 2.2. Limits to Total Transfer Capability

\subsection{Stabilitas sistem tenaga}

Secara umum stabilitas pada suatu sistem tenaga diklasifikasikan menjadi 3 kategori berdasarkan waktu terjadinya[5] yaitu :

a. Stabilitas steady state

Stabilitas steady state adalah kemampuan sistem tenaga listrik untuk tetap menjaga sinkronisasi antara mesin-mesin pada sistem setelah mengalami gangguan kecil.

b. Stabilitas dinamis

Stabilitas dinamis adalah kemampuan sistem untuk tetap mempertahankan kondisi sinkron setelah terjadi ayunan pertama (periode stabilitas transient) sampai sistem mencapai kondisi steady-state yang baru (stabilitas transient bila AVR dan governor bekerja cepat dan diperhitungkan dalam analisis).

c. Stabilitas transien.

Stabilitas transien adalah kemampuan sistem tenaga untuk mencapai kondisi stabil pada kondisi operasi yang baru yang dapat diterima setelah sistem mengalami gangguan berskala besar dalam kurun waktu selama 1 swing (ayunan) pertama dengan asumsi AVR dan generator belum bekerja karena dalam periode transien, seperti gangguan sistem transmisi, perubahan beban yang mendadak dari terputusnya unit pembangkitan atau switching pada saluran [6]. 


\subsection{Sistem Interkoneksi Sumatera Bagian Selatan (Sumbagsel)}

Sistem interkoneksi Sumatera Bagian Selatan dihubungkan oleh Saluran Transmisi Tegangan Tinggi (SUTT) dengan tegangan nominal 150 $\mathrm{kV}$. Pada wilayah Palembang jumlah transmisi sebanyak 39 saluran, untuk bengkulu sebanyak 13 saluran serta wilayah Lampung sebanyak 42 saluran, namun dari 39 saluran pada UPT Palembang terdapat satu Tragi yaitu Tragi Boom Baru yang menggunakan sirkit $70 \mathrm{kV}$. Sistem Sumatera Selatan terkoneksi dengan wilayah Bengkulu melalui transmisi $150 \mathrm{kV}$ pada GI Lubuk Linggau-Pekalongan sejauh 69,60 km, sedangkan sistem Lampung terkoneksi dengan sistem Sumatera Selatan melalui 2 penghantar transmisi pada GI Bukit Kemuning-Baturaja sejauh 98,90 km dan GI Blambangan UmpuBaturaja sejauh 59,834 km.

Sistem interkoneksi sumbagsel ini bertujuan untuk memenuhi kebutuhan listrik pada suatu wilayah. Dalam hal ini sistem Lampung adalah wilayah yang membutuhkan pasokan listrik dari sistem Sumatera Selatan. Pada saat ini Lampung mampu menghasilkan 458 MW dengan defisit daya 104,628 MW saat waktu beban puncak (WBP) dan menghasilkan 355,8 MW saat luar waktu beban puncak (LWBP) dengan defisit daya 25,252 MW. Adapun PLTA Batutegi yang hanya dapat beroperasi 1 unit sebesar 12,6 MW saat beban puncak dan pada saat luar waktu beban puncak tidak dioperasikan, sedangkan PLTA Way Besai hanya 1 unit yang beroperasi sebesar 44,8 MW pada saat luar waktu beban puncak, hal ini dikarenakan untuk menghemat keterbatasan debit air. Solusi untuk mengganti rugi-rugi daya yang disalurkan dengan beberapa pembangkit yang merupakan PLTD belum cukup efektif, karena akan memerlukan biaya bahan bakar lebih mahal, sehingga sistem pengoperasiannya pun terbatas. Pada wilayah Bengkulu sebenarnya masih mampu untuk memenuhi kebutuhan beban sebesar 99,148 MW dengan total pembangkitan mencapai 226 MW, namun pembangkit pada wilayah ini merupakan pembangkit listrik dengan sumber daya air (PLTA Musi dan PLTA TESS) yang pada saat musim kemarau akan kekurangan pasokan air dan pada saat melakukan maintenance tetap akan membutuhkan pasokan listrik dari wilayah Palembang.

\section{METODOLOGI PENELITIAN}

Metode yang digunakan untuk menyelesaikan aliran daya pada tugas akhir ini menggunakan solusi Continuation Power Flow (CPF) pada toolbox PSAT Matlab [7],[8] dengan langkah prediksi dan koreksi yang merupakan langkah solusi untuk menyelesaikan aliran daya untuk menentukan kenaikan $\lambda$ (faktor pengali kenaikan beban) .

\section{Persamaan Aliran daya}

Persamaan aliran daya untuk fasa $p$ pada saluran tiga fasa busikoordinat polar dapat diperoleh dari persamaan berikut :

$$
\begin{aligned}
& P_{i}^{p}=\sum_{j \in i, n=a, b, c} V_{i}^{p} V_{j}^{m}\left[G_{i j}^{p m} \cos \left(\theta_{i}^{p}-\theta_{j}^{m}\right)+B_{i j}^{p m} \sin \left(\theta_{i}^{p}-\right.\right. \\
& \left.\left.\theta_{j}^{m}\right)\right] \\
& Q_{i}^{p}=\sum_{j \in i, n=a, b, c} V_{i}^{p} V_{j}^{m}\left[g_{i j}^{p m} \sin \left(\theta_{i}^{p}-\theta_{j}^{m}\right)+b_{i j}^{p m} \cos \left(\theta_{i}^{p}-\right.\right. \\
& \left.\left.\theta_{j}^{m}\right)\right]
\end{aligned}
$$

Dimana subskrib $i$ dan $j$ merepresentasikan nomor bus tiga fasa, sedangkan subskrib $p$ dan $m$ menunjukkan fasa bus yang sesuai.

Total daya aktif dan reaktif pada bus generator di koordinat polar yang direpresentasikan sebagai fungsi dari terminal generator dan tegangan ditunjukkan oleh:

$$
\begin{aligned}
& P_{i}^{\Sigma}=-\sum_{p=a, b, c} \quad \sum_{m=a, b, c} V_{i}^{p} V_{i}^{m}\left[G g e n_{i}^{p m} \cos \left(\theta_{i}^{p}-\theta_{j}^{m}\right)+\right. \\
& \left.B g e n_{i}^{p m} \sin \left(\theta_{i}^{p}-\theta_{j}^{m}\right)\right]+ \\
& \sum_{p=a, b, c} \quad \sum_{n=a, b, c} V_{i}^{p} E_{i}^{m}\left[G g e n_{i}^{p n} \cos \left(\theta_{i}^{p}-\delta_{j}^{m}\right)+B g e n_{i}^{p n} \sin \left(\theta_{i}^{p}-\right.\right. \\
& \left.\left.\delta_{j}^{m}\right)\right] \\
& Q_{i}^{\sum}=-\sum_{p=a, b, c} \quad \sum_{m=a, b, c} V_{i}^{p} V_{i}^{m}\left[\operatorname{Ggen}_{i}^{p n} \sin \left(\theta_{i}^{p}-\theta_{j}^{m}\right)+\right. \\
& \left.B g e n_{i}^{p m} \cos \left(\theta_{i}^{p}-\theta_{j}^{m}\right)\right] \\
& +\sum_{p=a, b, c} \quad \sum_{m=a b, c} V_{i}^{p} E_{i}^{m}\left[\operatorname{Ggen}_{i}^{p n} \sin \left(\theta_{i}^{p}-\delta_{j}^{m}\right)+\right. \\
& \left.\operatorname{Bgen}_{i}^{p m} \cos \left(\theta_{i}^{p}-\delta_{j}^{m}\right)\right]
\end{aligned}
$$

${\text { Dimana } \text { Ggen }_{i} \text { dan Bgen }}_{i}$ merupakan matrik 3x3, yang diberikan masing masing oleh bilangan real $\left(\right.$ Ygen $\left._{i}\right)$ dan bilangan imaginer $\left(\right.$ Ygen $\left._{i}\right)$.

Persamaan mismatch aliran daya pada bus ditunjukkan oleh: 


$$
\begin{aligned}
& \Delta P_{i}^{p}=-P d_{i}^{p}-P_{i}^{p}=0 \\
& \Delta Q_{i}^{p}=-Q d_{i}^{p}-Q_{i}^{p}=0
\end{aligned}
$$

Dimana $\boldsymbol{P} \boldsymbol{d}_{\boldsymbol{i}}^{\boldsymbol{p}}$ dan $\boldsymbol{Q} \boldsymbol{d}_{\boldsymbol{i}}^{\boldsymbol{p}}$ merupakan daya aktif dan reaktif beban.

Selain persamaan (5) dan (6) pada beban, persamaan untuk daya aktif dan reaktif juga didapat dari persamaan :

$$
\begin{aligned}
& \Delta P g_{i}=P g_{i}-P_{i}^{\Sigma}=0 \\
& \Delta Q g_{i}=Q g_{i}-Q_{i}^{\Sigma}=0
\end{aligned}
$$

Dimana $\quad \boldsymbol{P} \boldsymbol{g}_{\boldsymbol{i}}$ dan $\quad \boldsymbol{Q g}_{\boldsymbol{i}}$ masing-masing merupakan daya aktif dan daya reaktif generator.

Ini menunjukkan bahwa persamaan (8) hanya berlaku ketika mesin sinkron adalah PQ machine. Untuk PV machine, persamaan (8) perlu diganti dengan persamaan kendala tegangan. Sebagai berikut :

$$
\Delta V g_{i}=V g_{i}^{\text {Spec }}-V g_{i}^{1}=0
$$

Dimana $V g_{i}^{1}$ merupakan tegangan urutan positif bus generator, sementara $V g_{i}^{S p e c}$ adalah tegangan referensi kontrol urutan positif yang ditentukan.

Dalam rangka menyederhanakan presentasi, persamaan (8) dan (9) dapat ditulis sebagai berikut:

$$
\Delta R g_{i}=\left\{\begin{array}{l}
\Delta Q g_{i}, P Q \text { machine } \\
\Delta V g_{i}, P V \text { machine }
\end{array}\right.
$$

Untuk mensimulasikan perubahan beban, $P d_{i}^{p}$ dan $Q d_{i}^{p} \quad$ dapat direpresentasikan oleh persamaan:

$$
\begin{aligned}
& P d_{i}^{p}=P d 0_{i}^{p}\left(1+\lambda^{*} K P d_{i}^{p}\right) \\
& Q d_{i}^{p}=Q d 0_{i}^{p}\left(1+\lambda^{*} K Q d_{i}^{p}\right)
\end{aligned}
$$

Dimana nilai $\lambda$ adalah parameter beban, dengan karakteristik perubahan beban. Rasio dari $K P d_{i}^{p} / \quad K Q d_{i}^{p}$ adalah konstan untuk mempertahankan konstannya faktor daya.
Demikian juga untuk mensimulasikan perubahan generator, $P g_{i}$ dan $Q g_{i}$ dapat direpresentasikan sebagai fungsi dari $\lambda$, ditunjukkan oleh:

$$
\begin{aligned}
& P g_{i}=P g 0_{i}\left(1+\lambda^{*} K P g_{i}\right) \\
& Q g_{i}=Q g 0_{i}\left(1+\lambda^{*} K Q g_{i}\right)
\end{aligned}
$$

Untuk $P V$ machine ,persamaan (14) tidak diperlukan.

Persamaan non-linear (5),(6),(7),(10) yang ditambah oleh variable tambahan $\lambda$ sebagai berikut :

$$
f(x, \lambda)=0
$$

Dimana $f(x, \lambda)$ mewakili seluruh rangkaian persamaan mismatch aliran daya. $x$ adalah variable vektor yang ditunjukkan oleh :

$$
x=\left[\theta^{a}, V^{a}, \theta^{b}, V^{b}, \theta^{c}, V^{c}, \delta^{a}, E^{a}\right]
$$

\section{Langkah Prediksi}

Langkah prediksi digunakan untuk memberikan titik perkiraan pada solusi berikutnya. Sebuah prediksi pada solusi berikutnya diambil dari langkah tepat pada arah tangen.

Persamaan (15) dapat diselesaikan oleh continuation algoritma dengan langkah prediksi dan koreksi. Ditunjukkan oleh:

$$
\boldsymbol{d} \boldsymbol{f}(x, \lambda)=f_{x} d x+f_{\lambda} d \lambda=0
$$

Untuk menyelesaikan (16), diperlukan satu persamaan lanjutan. Jika memilih magnitude nilai bukan nol untuk salah satu tangen vektor dan menjaga perubahannya sekitar \pm 1 , satu persamaan tambahan dapat diperoleh, yaitu :

$$
t_{k}= \pm 1
$$

Dimana $t_{k}$ adalah elemen bukan nol dari tangen vektor $\boldsymbol{d} \boldsymbol{x}$.

Dengan menggabungkan persamaan (16) dan (17), akan didapatkan satu set persamaan yang mana tangen vektor $d x$ dan $d \lambda$ adalah variable yang tidak diketahui.

$$
\left[\frac{f_{x} f_{\lambda}}{e_{k}}\right]\left[\frac{d x}{d \lambda}\right]=\left[\frac{0}{ \pm 1}\right]
$$

Dimana $e_{k}$ adalah vektor baris dengan semua elemen nol kecuali untuk elemen kth yang bernilai satu.

Pada persamaan (18) nilai +1 atau -1 digunakan tergantung pada bagaimana 
perubahan variable $k t h$ sebagai solusi yang sedang ditelusuri.

Setelah menyelesaikan (18), suatu prediksi solusi berikutnya akan ditunjukkan pada persamaan :

$$
\left[\frac{x^{2}}{\lambda}\right]=\left[\frac{x}{\lambda}\right]+\sigma\left[\frac{d x}{d \lambda}\right]
$$

Dimana * menunjukkan solusi perkiraan untuk langkah selanjutnya pada saat nilai $\sigma$ adalah skalar, yang merupakan ukuran tahapan.

\section{Langkah koreksi}

Langkah koreksi bertujuan untuk menyelesaikan penambahan aliran daya Newton dengan solusi prediksi pada (19) sebagai titik awal (initial point). Pada algoritma aliran daya Newton persamaan tambahan disertakan dan $\lambda$ diambil sebagai variabel. Persamaan aliran daya Newton itu ditunjukkan pada:

$$
\left[\frac{f(x, \lambda)}{x_{k}-\eta}\right]=\left[\frac{0}{0}\right]
$$

Dimana $\eta$ merupakan nilai yang sesuai untuk elemen kth pada $\boldsymbol{x}$. Persamaan (20) ini dapat diselesaikan dengan metode Newton.

\section{HASIL DAN PEMBAHASAN}

\subsection{Data Pembangkitan dan Pembebanan Interkoneksi Sumbagsel}

Sistem interkoneksi Sumatera Bagian Selatan (sumbagsel) yang ditinjau terdiri dari 3 UPT yaitu : wilayah Sumatera Selatan, wilayah Bengkulu serta wilayah Lampung. Sistem Sumbagsel ini terdiri dari 200 bus, 94 saluran, 156 transformator, 66 generator dan 77 beban.

Tabel 4.1. Total Data Pembangkitan dan Beban Sumbagsel

\begin{tabular}{|cc|c|c|c|}
\hline No & Wilayah kerja & $\begin{array}{c}\text { Pembangkit } \\
(\mathrm{MW})\end{array}$ & $\begin{array}{c}\text { LWBP } \\
\text { (MW) }\end{array}$ & $\begin{array}{c}\text { WBP } \\
(\mathrm{MW})\end{array}$ \\
\hline 1 & Sumatera Selatan & $\mathbf{1 0 0 4}$ & $\mathbf{3 6 2 , 9 2 5}$ & $\mathbf{5 6 8 , 3 3 8}$ \\
\hline 2 & Bengkulu & 226 & $\mathbf{6 4 , 4 3 9}$ & $\mathbf{9 9 , 1 4 8}$ \\
\hline 3 & Lampung & $\mathbf{4 7 0 , 6}$ & $\mathbf{3 8 1 , 0 5 2}$ & $\mathbf{5 6 2 , 6 2 8}$ \\
\hline & Total & $\mathbf{1 7 0 0 , 6}$ & $\mathbf{8 0 8 , 4 1 6}$ & $\mathbf{1 2 3 0 , 1 1 4}$ \\
\hline
\end{tabular}

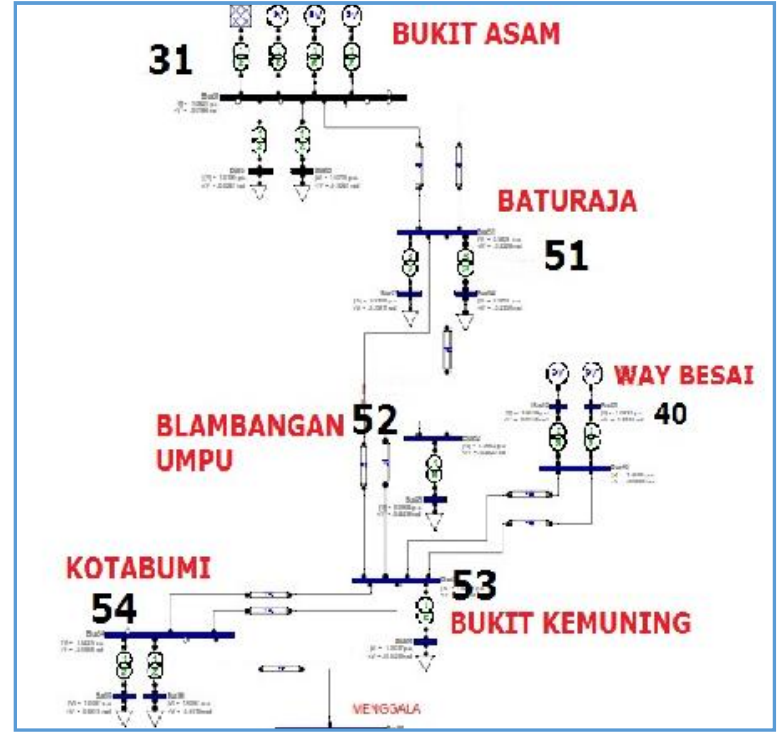

Gambar 4.1 Bus dan Saluran yang ditinjau

Pada gambar 4.1 menunjukkan bus-bus dan saluran pada sistem Sumbagsel yang ditinjau dari penelitian ini yaitu bus Bukit Asam, Baturaja, Blambangan Umpu, Bukit Kemuning dan Kotabumi. Slack bus ditempatkan di salah satu generator pada bus Bukit Asam dan Saluran yang menghubungkan bus-bus tersebut menggunakan transmisi $150 \mathrm{kV}$.

Hasil simulasi CPF pada saat luar waktu beban puncak dan waktu beban puncak pada masing masing bus yang menghubungkan Sumatera Selatan dan Lampung didapatkan berupa data, sebagai berikut:

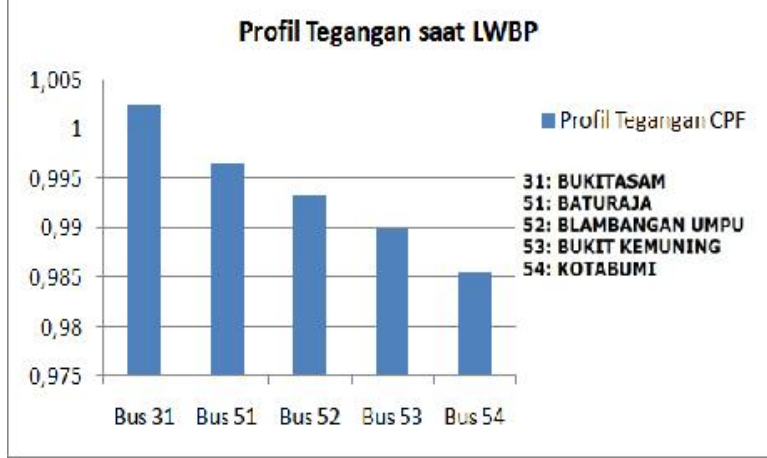

Gambar 4.2. Profil Tegangan CPF saat LWBP

Pada gambar 4.2 dapat terlihat bahwa nilai tegangan pada bus Kotabumi (54) adalah bus dengan nilai tegangan paling kecil sebesar 0,98548 atau $147,8222 \mathrm{kV}$. Tegangan pada bus Baturaja (51) $149,4787 \mathrm{kV}$ atau 0,99652 pu, pada bus Blambangan Umpu (52) memiliki tegangan sebesar 148,9866 kV atau 0.99324 pu. Tegangan pada bus Bukit Kemuning sebesar 148,4868 kV 
atau 0.98991 pu. Sedangkan bus 31 pada bus Bukit Asam memiliki tegangan paling besar yaitu $150,378 \mathrm{kV}$ atau sebesar $1,0025 \mathrm{pu}$.

Sedangkan untuk hubungan antara tegangan tiap bus dengan loading parameter pada saat luar waktu beban puncak ditunjukkan dengan $P V$ Curve sebagai berikut:

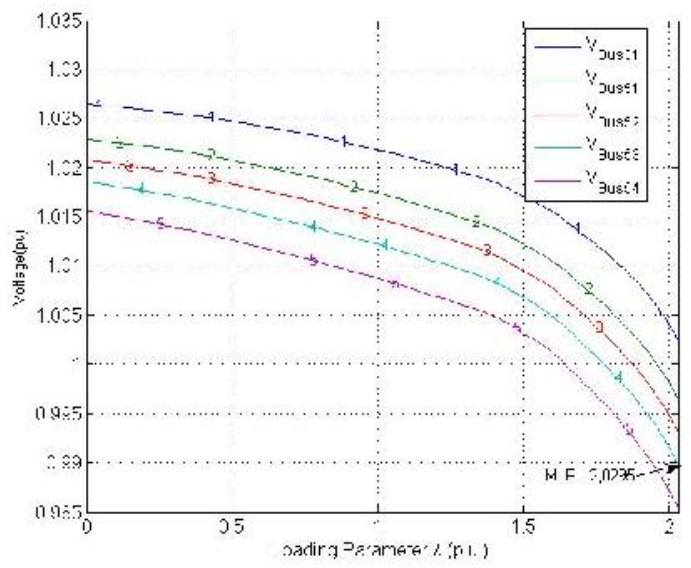

Gambar 4.3. PV Curves CPF saat LWBP

Berdasarkan gambar 4.3. kurva nomor 1, 2, 3, 4, 5 berturut-turut merupakan nilai tegangan pada bus $31,51,52,53$, dan 54 dengan tegangan pada tiap bus dari hasil simulasi menunjukkan terjadinya penurunan. Dari grafik PV ini didapatkan nilai parameter pembebanan maksimum sebesar 2,0295. Nilai ini akan menjadi acuan penambahan beban pada simulasi berikutnya.

Pada simulasi CPF dengan data saat waktu beban puncak ditunjukkan pada gambar profil tegangan CPF berikut:

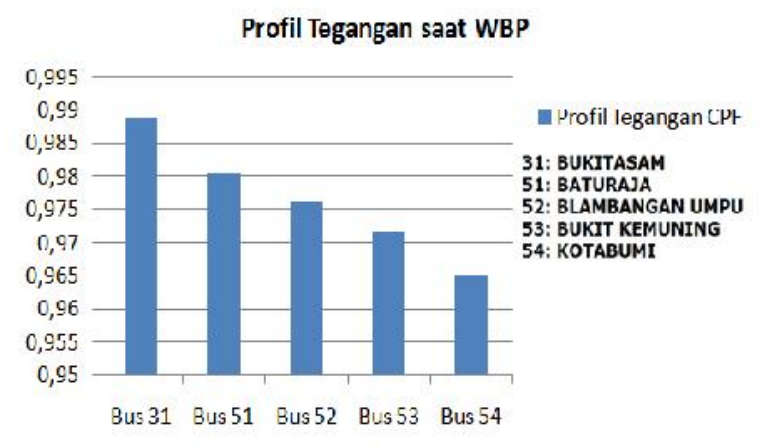

Gambar 4.4. Profil Tegangan CPF saat WBP

Berdasarkan gambar 4.7 terlihat bahwa nilai tegangan CPF pada saat waktu beban puncak lebih kecil dibandingkan dengan tegangan pada luar waktu beban puncak. Beban yang harus ditransfer oleh sistem sangat mempengaruhi nilai tegangan dari tiap bus GI. Saat waktu beban puncak tegangan pada bus Bukit Asam sebesar 0,98878 pu atau $148,3169 \mathrm{kV}$, pada bus Baturaja sebesar 0,98059 pu atau 147,0888 $\mathrm{kV}$, bus Blambangan Umpu memiliki tegangan sebesar $0,97611 \mathrm{pu}$ atau $146,4162 \mathrm{kV}$, untuk bus Bukit Kemuning sebesar 0,97157 pu atau $145,736 \mathrm{kV}$ sedangkan pada bus Kotabumi sebesar 0,96525 pu atau $144,7878 \mathrm{kV}$ yang merupakan tegangan CPF paling kecil dibanding bus ditinjau CPF lainnya. Hubungan antara tegangan tiap bus yang ditinjau dengan loading parameter pada saat waktu beban puncak ditunjukkan dengan $P V$ Curve sebagai berikut:

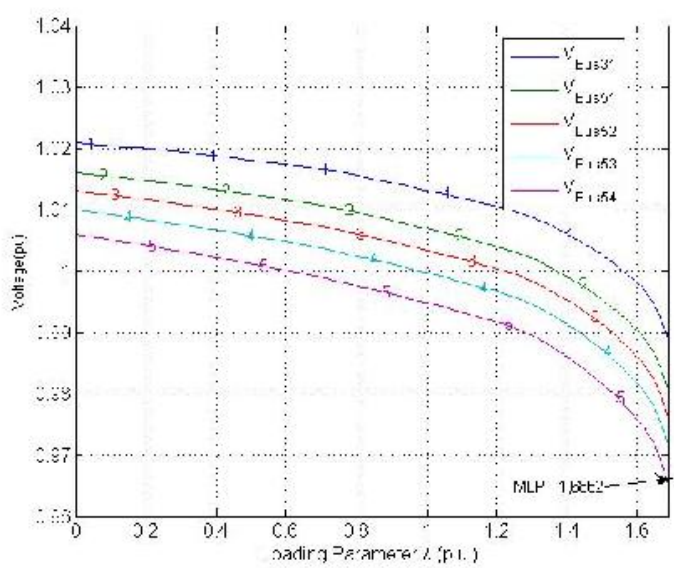

Gambar 4.5. PV Curves CPF saat WBP

Gambar 4.5 menunjukkan kurva PV pada tegangan bus ditinjau; saat waktu beban puncak dengan nilai lambda maksimum nya sebesar 1,6862. Tegangan paling kecil merupakan bus kotabumi dengan 0,96525 pu. Total beban yang lebih besar pada saat waktu beban puncak menyebabkan nilai parameter pembebanan semakin kecil.

\subsection{Aliran Daya antar Bus CPF}

Besarnya daya aktif dan daya reaktif yang dapat disalurkan pada saluran antar bus sistem interkoneksi pada saat luar waktu beban puncak (LWBP) dan waktu beban puncak (WBP) yang ditinjau dapat telihat dari Line Flow hasil simulasi CPF berikut: 


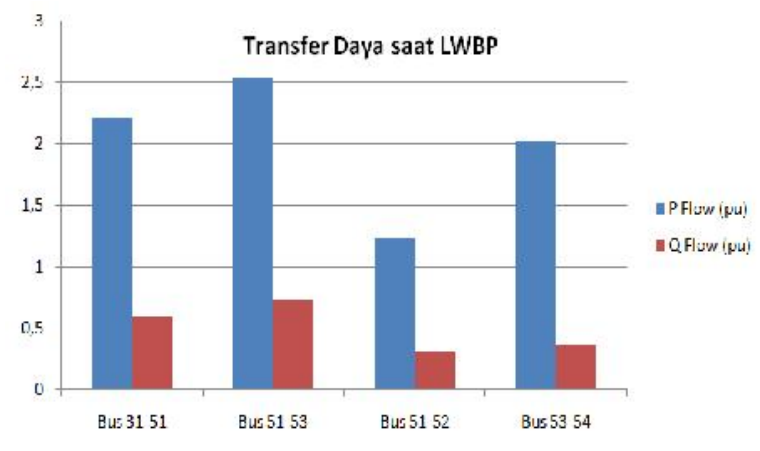

Gambar 4.6. Transfer Daya antar bus LWBP

Dari gambar 4.6 menunjukkan besarnya masingmasing daya yang disalurkan tiap bus. Daya aktif terbesar yang disalurkan terdapat pada bus 51-53 yang merupakan bus yang menghubungkan Baturaja - Bukit Kemuning sebesar 254,0898 MW, sedangkan transfer daya paling kecil terdapat pada bus yang menghubungkan Baturaja - Blambangan Umpu atau bus 51-52 sebesar 123,1831 MW. Daya reaktif yang disalurkan terbesar terdapat pada saluran 51-53 yang menghubungkan Baturaja - Bukit kemuning sebesar 72,8803 Mvar. Transfer daya antar bus pada saat waktu beban puncak (WBP) dapat terlihat pada gambar 4.6 berikut:

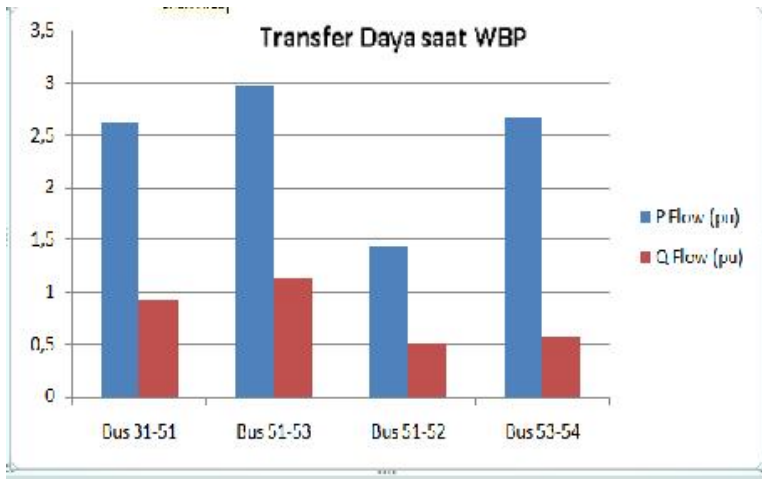

Gambar 4.7. Transfer Daya antar bus WBP

Pada saat transfer daya waktu beban puncak memiliki daya yang lebih besar dibandingkan dengan transfer daya luar waktu beban puncak. Hal ini disebabkan total beban yang lebih besar, sehingga menyebabkan generator membangkitkan daya yang lebih besar juga agar kontinuitas pelayanan beban tetap terjaga dengan baik. Transfer daya terbesar terdapat pada saluran 51-53 Baturaja - Bukit Kemuning sebesar 296,8438 MW. Daya reaktif yang ditransfer pada saluran Baturaja-Bukit Kemuning sebesar 112,6502 Mvar yang merupakan daya reaktif terbesar dari bus ditinjau lainnya.

\subsection{Penambahan Beban 10 MW setiap beban Lampung}

Untuk mengetahui besar transfer daya maksimum yang masih dapat diterima pada bus yang menghubungkan area Sumatera Selatan dan Lampung dilakukan scenario penambahan beban sebesar 10 MW pada setiap beban wilayah Lampung. Dari hasil scenario tersebut didapatkan data:

Tabel 4.8. Penambahan beban terhadap perubahan tegangan saat LWBP

\begin{tabular}{|c|c|c|c|c|c|c|}
\hline \multirow{2}{*}{$\begin{array}{c}\text { Began PQ } \\
\text { (MW) }\end{array}$} & \multicolumn{5}{|c|}{ Nomor Bis } & \multirow[b]{2}{*}{ MLP } \\
\hline & $\begin{array}{l}\text { Bus 31 } \\
(\mathrm{kV})\end{array}$ & $\begin{array}{l}\text { Bus } 51 \\
(\mathrm{kV})\end{array}$ & $\begin{array}{l}\text { Bus } 52 \\
(\mathrm{kV})\end{array}$ & $\begin{array}{l}\text { Bus 53 } \\
(\mathrm{kV})\end{array}$ & $\begin{array}{l}\text { Bus } 54 \\
(\mathrm{kV})\end{array}$ & \\
\hline \multirow[t]{2}{*}{ PQNormal } & & & & & & \\
\hline & 150,378 & 149,4737 & 148,9866 & 148,4863 & 147,8222 & 2,0295 \\
\hline$\overline{P Q}+10 \mathrm{MW}$ & 142,3741 & 140,0057 & $138,55 \mathrm{Cg}$ & 137,1594 & 135,1289 & 1,3024 \\
\hline$\overline{P Q}+20 \mathrm{MW}$ & 133.8435 & 130.8231 & 128.9348 & 127.1403 & 124.4829 & 0,86787 \\
\hline$\overline{P Q}+30 \mathrm{MW}$ & 133.364 & 130.1433 & 128.1647 & 126.2879 & 123.499 & 0,63652 \\
\hline $\mathrm{PQ}+40 \mathrm{MW}$ & 132.2174 & 128.9508 & $126.89 \mathrm{C} 2$ & 124.944 & 122.0489 & 0,50246 \\
\hline $\mathrm{PQ}+50 \mathrm{MW}$ & 132.2812 & 128.9738 & 126.8826 & 124.9103 & 121.9736 & 0.41442 \\
\hline $\mathrm{PQ}+60 \mathrm{MW}$ & 126.5658 & 123.2125 & $121.07 \mathrm{C6}$ & 119.1013 & 116.1449 & 0.39705 \\
\hline $\mathrm{PQ}+70 \mathrm{MW}$ & 118.3333 & 114.5857 & 112.2117 & 109.97 & 106.634? & 0.29168 \\
\hline $\mathrm{PQ}+80 \mathrm{MW}$ & 114.6314 & 110.7533 & 108.3051 & 105.9893 & 102.5435 & 0.2531 \\
\hline $\mathrm{PQ}+90 \mathrm{MW}$ & 111.3231 & 107.3473 & 104.825 & 102.4444 & 98.9027 & 0.22335 \\
\hline $\mathrm{PQ}+100 \mathrm{MW}$ & 108.1245 & 104.0412 & 101.4536 & 99.0094 & 95.3719 & 0.19735 \\
\hline$P Q+110 \mathrm{MW}$ & 105.3234 & $101.15) 9$ & 98.5034 & 96.0015 & 92.2781 & 0.17689 \\
\hline $\mathrm{PQ}+120 \mathrm{MW}$ & 102.7226 & 98.4552 & 95.7505 & 93.1935 & 89.3878 & 0,15974 \\
\hline$\overline{P Q}+130 \mathrm{MW}$ & 100.3254 & 95.973 & 93.2145 & 90.6053 & 86.7217 & 0,14519 \\
\hline $\mathrm{PQ}+140 \mathrm{MW}$ & 98.095 & 93.6616 & 90.8519 & 88.1925 & 84.2344 & 0,13269 \\
\hline $\mathrm{PQ}+150 \mathrm{MW}$ & 100.7896 & 97.1244 & 94.8807 & 92.5364 & 88.9595 & 0 \\
\hline $\mathrm{PQ}+160 \mathrm{MW}$ & 0.00015 & 7.637 & 0.13643 & 0.00015 & 12.3149 & 0 \\
\hline $\mathrm{PQ}+170 \mathrm{MW}$ & 108.1033 & 91.1286 & 80.7043 & 69.7195 & 53.2283 & 0 \\
\hline $\mathrm{PQ}+180 \mathrm{MW}$ & 57.6407 & 0.727 & 216.0319 & 3.1238 & 26.5662 & 0 \\
\hline $\mathrm{PQ}+190 \mathrm{MW}$ & 102.3737 & 60.216 & 36.8949 & 16.6861 & 0.00015 & 0 \\
\hline$\overline{P Q}+200 \mathrm{MW}$ & 136.4737 & 121.2261 & 111.9175 & 102.2187 & 91.3204 & \\
\hline
\end{tabular}

Berdasarkan tabel 4.8 menunjukkan nilai tegangan pada tiap bus yang ditinjau dengan masing-masing penambahan 10 MW sampai 200 MW. Pada tabel ini juga terlihat nilai Maksimum Loading Parameters (MLP) yang dihasilkan dari simulasi semakin menurun dengan beban yang terus bertambah. Setiap penambahan 10 MW mengakibatkan nilai tegangan menurun karena besarnya beban yang ditambahkan berbanding terbalik dengan nilai tegangan pada tiap bus. Pada penambahan 150 MW terlihat nilai MLP adalah nol, hal ini menunjukkan bahwa dengan penambahan beban tersebut nilai tegangan sudah tidak stabil dan transfer daya sudah tidak diijinkan. 


\subsection{Transfer Daya pada Saluran saat LWBP}

Tabel 4.9. Daya saluran antar bus yang ditinjau

\begin{tabular}{|c|c|c|c|c|}
\hline \multirow{2}{*}{$\begin{array}{c}\text { Beban PQ } \\
\text { (MV) }\end{array}$} & \multicolumn{4}{|c|}{ Daya tian saluran antar Bus } \\
\hline & $31-51$ (MV) & $51-53$ (MN) & $51-52$ (MiV) & $53-54$ (MW) \\
\hline PQ Normal & 221.2146 & 254.0898 & 123.1831 & 203.2458 \\
\hline$P Q+10 M W$ & 310.2599 & 382.6249 & 192.112 & 287.6628 \\
\hline$P Q+20 M W$ & 322.9119 & 405.7799 & 205.6866 & 298.847 \\
\hline $\mathrm{PQ}+30 \mathrm{MW}$ & 316.488 & 401.1635 & 204.4014 & 293.56 \\
\hline$P Q+40 \mathrm{MW}$ & 314.6045 & 400.8635 & 204.7838 & 291.8749 \\
\hline$P Q+50 M W$ & 313.0505 & 400.1388 & 204.8437 & 290.5927 \\
\hline $\mathrm{PQ}+50 \mathrm{MW}$ & $251.221 \mathrm{C}$ & $31 C . .50 C 0$ & 167.4360 & 224.0025 \\
\hline$P Q+70 M W$ & 298.8841 & 382.446 & 196.3314 & 275.5568 \\
\hline $\mathrm{Dn}+R \cap \mathrm{MW}$ & 2924231 & 3755251 & 1929239 & 3699191 \\
\hline$P Q+90 M W$ & 289.1272 & 370.045 & 190.301 & 265.3951 \\
\hline$P Q+100 M W$ & 282.5245 & 361.4389 & 186.0578 & 258.7063 \\
\hline$P Q+110 M W$ & 277.5731 & 354.5411 & 182.845 & 253.5868 \\
\hline $\mathrm{DQ}+120 \mathrm{MW}$ & 272.8102 & 318.6112 & 179.7196 & 218.6178 \\
\hline$P Q+130 M W$ & 268.2519 & 342.5771 & 176.7041 & 243.9134 \\
\hline $\mathrm{PO}+140 \mathrm{MW}$ & 263.8278 & 336.6633 & 1737575 & 239.3147 \\
\hline $\mathrm{PQ}+150 \mathrm{MW}$ & 15.0437 & 9.6505 & 11.8095 & 5.7976 \\
\hline$P Q+160 M W$ & 0.00107 & 18.7016 & 18.1621 & 0.00177 \\
\hline$P Q+170 M W$ & 636.8111 & 732.6538 & 371.0271 & 464.7471 \\
\hline$P Q+180 M W$ & 1014.8355 & 2.4497 & -151.393 & -1.9308 \\
\hline$P Q+190 M W$ & 53.4355 & 1143.9443 & -346.615 & 84.0099 \\
\hline $\mathrm{PQ}+200 \mathrm{MW}$ & 228.5368 & 188.2656 & 125.061 & 71.0578 \\
\hline
\end{tabular}

Tabel 4.9 menunjukkan bahwa besarnya nilai transfer daya pada tiap-tiap saluran yang ditinjau. Pada keadaan PQ normal atau sebelum penambahan beban, nilai transfer daya pada 4 saluran yang ditinjau paling besar terdapat pada saluran Baturaja - Bukit Kemuning (51-53) yaitu 254.0898 MW. Transfer daya maksimum terjadi pada penambahan beban sebesar 140 MW dengan nilai daya terbesar terdapat pada saluran yang menghubungkan Baturaja-Bukit Kemuning (51-53) sebesar 336,6633 MW. Penambahan beban PQ+150 sudah tidak diizinkan karena nilai transfer daya yang terjadi sudah tidak konvergen lagi.

Tabel 4.10. Penambahan beban terhadap perubahan tegangan saat WBP

\begin{tabular}{|c|c|c|c|c|c|c|}
\hline \multirow{2}{*}{$\begin{array}{c}\text { Betan } P(2) \\
\text { (MN) }\end{array}$} & \multicolumn{5}{|c|}{ Aomar. Kins } & \multirow[b]{2}{*}{$\mathbf{M L F}$} \\
\hline & $\begin{array}{l}\mathrm{Bus} 31 \\
(\mathbf{k V})\end{array}$ & Bus $51(\mathrm{kV})$ & $\begin{array}{l}\text { Bus 52 } \\
(\mathrm{kV})\end{array}$ & Bas $53(\mathrm{kV})$ & Bas $34(\mathrm{kV})$ & \\
\hline PQ Norman & & 147,0858 & & 145,736 & 144,7378 & 1,6862 \\
\hline $\mathrm{P}_{2}+10 \mathrm{MNT}$ & 1357642 & 1333455 & 1313856 & 1364565 & 1233301 & 1,1113 \\
\hline$P Q+20 . M W$ & 1342622 & $151.23 \in 1$ & $129.3<11$ & 128.2423 & $123: / 695$ & 0,76291 \\
\hline $\mathrm{PO}+30 \mathrm{MWV}$ & 1336124 & 130.7091 & 128885 & 127.1691 & 124.5144 & 0,38429 \\
\hline $\mathrm{PQ}+40 \mathrm{MW}$ & 1289022 & 125.7911 & 123.3371 & 121.9568 & 110.1516 & 0.46433 \\
\hline $\mathrm{PQ}, 50 \mathrm{MW}$ & 1258524 & 122.5038 & 120.5572 & 118.6319 & 115.6562 & 0.38133 \\
\hline $\mathrm{PQ}+60 \mathrm{MW}$ & 1212709 & 117.3545 & 115693 & 113.6705 & 110.53995 & 0.32511 \\
\hline$P Q 2+78 \mathrm{MW}$ & 1183043 & $1147 \% 36$ & 112,468 & $111.4411 \mathrm{~K}$ & $101 / 19 \times 4$ & $(1) / 4) 4$ \\
\hline $\mathrm{PQ}+80 \mathrm{MW}$ & 1141853 & 110.5153 & 108.1997 & 106.0197 & $102.656 \mathrm{C}$ & 0.24521 \\
\hline & & & & $102 .+353$ & $9 \varepsilon .9691$ & \\
\hline$\frac{P Q+4}{P Q}$ & $\frac{1079723}{107}$ & $\frac{10707}{121.0977}$ & $\frac{1+.0026}{101.5 / 32}$ & $\frac{102.453}{993356}$ & $\frac{7.9671}{95.7776}$ & 0.219311 \\
\hline & $105 \$ 138$ & 101.7449 & $\$ 9.1681$ & 967412 & $93.0 C 81$ & 0.1768 \\
\hline $\mathrm{P} Q 2+1 \geq n \mathrm{MV}$ & 1035624 & 995353 & 969.84 & 945798 & 968714 & 015654 \\
\hline$P Q+130 \mathrm{MWY}$ & 1007342 & 96.6035 & 53.5847 & प्र1 3194 & $8 / .12$ & $0.145^{\prime 2}$ \\
\hline $\mathrm{PO}+140 \mathrm{MNT}$ & 99.0621 & 94.7885 & 52.0795 & 893253 & 83.5936 & $0.1332 \mathrm{j}$ \\
\hline $\mathrm{PQ}+150 \mathrm{MW}$ & 29.5454 & 55.5713 & 53.7232 & 213741 & 87.6774 & 0 \\
\hline $\mathrm{PQ}, 160 \mathrm{MW}$ & 1390651 & 10.4 & 671.5 & 492 & $96.7 \in 93$ & \\
\hline $\mathrm{PQ}+170 \mathrm{MW}$ & 37.3583 & 31. & 51.3 & 787964 & 71.719 & 0 \\
\hline$P(2+1 X I I M W$ & 1121979 & 96.8865 & 87.4841 & 775624 & 62.1871 & 0 \\
\hline$P Q+190 \mathrm{MW}$ & 1129554 & 59.3733 & 51.0859 & 824495 & 65.0987 & 0 \\
\hline $\mathrm{PO}+200 \mathrm{MN}$ & 1108749 & 56.0023 & 86.5252 & 774731 & 64.3417 & 0 \\
\hline
\end{tabular}

Pada saat waktu beban puncak nilai tegangan pada tiap bus yang ditinjau lebih kecil dibandingkan dengan nilai tegangan pada saat luar waktu beban puncak. Hal ini dapat diketahui dari MLP atau parameter pembebanan maksimum yang diperoleh dari hasil CPF. Nilai lambda yang diperoleh sistem pada saat waktu beban puncak adalah 1,6862 yang merupakan parameter pembebanan maksimum sejauh mana pembangkitan dapat dilakukan untuk memenuhi kebutuhan beban. Penambahan PQ+150 dengan tiap beban di Lampung ditambahkan sebesar 150 MW nilai pembebanan nya 0 , menandakan batas dari kestablian tegangan tiap bus sudah tidak dapat dijaga. Nilai tegangan paling besar terdapat pada bus Baturaja (51) sebesar 94,7885 kV yang masih dapat dijaga kestabilan nya pada penambahan $\mathrm{PQ}+140$.

\subsection{Transfer Daya pada Saluran saat WBP}

Tabel 4.11. Daya saluran antar bus yang ditinjau

\begin{tabular}{|c|c|c|c|c|}
\hline $\begin{array}{c}\text { Beban PQ } \\
(\mathrm{MW})\end{array}$ & \multicolumn{4}{|c|}{ Daxa tiap. saluran antar Bus } \\
\cline { 2 - 5 } & $31-51(\mathrm{MW})$ & $51-53(\mathrm{MW})$ & $51-52(\mathrm{MW})$ & $53-54(\mathrm{MW})$ \\
\hline $\mathrm{PQNomal}$ & 262,6114 & 296,8438 & 144,7098 & 267,5455 \\
\hline $\mathrm{PQ}+10 \mathrm{MW}$ & 311.8305 & 376.1747 & 188.5662 & 310.6424 \\
\hline $\mathrm{PQ}+20 \mathrm{MW}$ & 304.7031 & 375.9056 & 190.5498 & 302.4416 \\
\hline $\mathrm{PQ}+30 \mathrm{MW}$ & 303.2038 & 378.7278 & 192.9998 & 299.7071 \\
\hline $\mathrm{PQ}+40 \mathrm{MW}$ & 297.9218 & 374.6563 & 191.6083 & 293.2534 \\
\hline $\mathrm{PQ}+50 \mathrm{MW}$ & 293.8264 & 371.1633 & 190.2856 & 288.3474 \\
\hline $\mathrm{PQ}+60 \mathrm{MW}$ & 289.1691 & 366.2117 & 188.1097 & 282.7881 \\
\hline $\mathrm{PQ}+70 \mathrm{MW}$ & 283.4164 & 359.566 & 185.0259 & 276.4158 \\
\hline $\mathrm{PQ}+80 \mathrm{MW}$ & 279.0817 & 354.3983 & 182.5877 & 271.4908 \\
\hline $\mathrm{PQ}+90 \mathrm{MW}$ & 274.0638 & 348.2418 & 179.6078 & 265.8598 \\
\hline $\mathrm{PQ}+100 \mathrm{MW}$ & 269.2606 & 342.2502 & 176.6883 & 260.5174 \\
\hline $\mathrm{PQ}+110 \mathrm{MW}$ & 274.5357 & 349.1532 & 180.126 & 263.4293 \\
\hline $\mathrm{PQ}+120 \mathrm{MW}$ & 258.2738 & 328.2823 & 169.8366 & 248.7264 \\
\hline $\mathrm{PQ}+130 \mathrm{MW}$ & 256.5989 & 326.114 & 168.7232 & 246.2856 \\
\hline $\mathrm{PQ}+140 \mathrm{MW}$ & 255.5405 & 324.4741 & 168.0617 & 244.5338 \\
\hline $\mathrm{PQ}+150 \mathrm{MW}$ & 14.2778 & 8.6579 & 11.2614 & 5.7209 \\
\hline $\mathrm{PQ}+160 \mathrm{MW}$ & 6624.3272 & -357.4919 & -3986.7709 & 4878.834 \\
\hline $\mathrm{PQ}+170 \mathrm{MW}$ & 16.9823 & 11.4156 & 12.2243 & 6.7423 \\
\hline $\mathrm{PQ}+180 \mathrm{MW}$ & 518.4158 & 593.7923 & 305.0197 & 406.2638 \\
\hline $\mathrm{PQ}+190 \mathrm{MW}$ & 180.7349 & 150.5937 & 97.3453 & 67.1783 \\
\hline $\mathrm{PQ}+200 \mathrm{MW}$ & 210.2802 & 174.7929 & 110.1366 & 72.9872 \\
\hline
\end{tabular}

Transfer daya yang terjadi pada waktu beban puncak bernilai lebih besar dibandingkan dengan pada luar beban puncak. Transfer daya maksimum yang dapat dilakukan sebesar 324,4741 MW pada saluran Baturaja - Bukit Kemuning. Peningkatan transfer daya sebesar 27,6303 MW dari saat beban puncak normal (PQ normal) sampai simulasi penambahan $\mathrm{PQ}+140$ MW pada tiap beban menandakan pembangkitan maksimal mencapai kenaikan 140 MW tiap beban di wilayah Lampung. Pada saat penambahan beban $\mathrm{PQ}+150$ transfer daya sudah tidak konvergen dan tidak dapat diizinkan, hal ini dapat terlihat bahwa kenaikan nilai transfer daya sudah tidak stabil.

\section{SIMPULAN DAN SARAN}

\subsection{Kesimpulan}

Berdasarkan simulasi dan pembahasan yang telah dilakukan, dapat disimpulkan hal-hal sebagai berikut:

a. Dengan kondisi pembangkitan saat ini maka transfer daya maksimum dapat ditingkatkan 
dengan menambahkan 10 MW di setiap beban GI wilayah Lampung, dengan tetap menjaga kondisi kestabilan tegangan pada setiap bus maka penambahan beban maksimum mencapai $140 \mathrm{MW}$.

b. Transfer daya maksimum pada sistem Interkoneksi Sumbagsel pada saat ini belum optimal sehingga dapat ditingkatkan dengan kenaikan daya sebesar $32,498 \%$ pada saat luar waktu beban puncak dan pada saat waktu beban puncak kenaikan daya $9,31 \%$. Tegangan pada bus Baturaja saat luar waktu beban puncak menurun sebesar $37,74 \%$ dan saat waktu beban puncak menurun 35,57\%.

\subsection{Saran}

Berdasarkan hasil analisa dan kesimpulan dari penelitian, maka penulis memberikan saran yaitu: Untuk penelitian aliran daya selanjutnya, agar lebih mempertimbangkan limit pembangkit pada sistem agar hasil simulasi lebih optimal.

\section{DAFTAR PUSTAKA}

[1] http://www.pln.co.id/lampung/?p=201, publikasi tanggal 13 april 2011, akses tanggal 19 Mei 2013

[2] Shao-Hua Li and Hsiao-Dong Chiang, "Continuation Power Flow With Nonlinier Power Injectiom Variation: A Piecewise Linier Approximation", IEEE Transaction On Power Systems, Vol. 23, No. 4, November 2008. pp. 1637-1643

[3] L.Hakim, J. Kubokawa, N.Yorino, Y. Zoka, Y. Sasaki, Total Transfer Capability Assessment Incorporating Corrective Controls for Transient Stability UsingTSCOPF, IEEJ Transaction On Power and Energy, Vol.130, Issue 4, 2010. pp. 339406

[4] North American Electric Reliability Council, Available Transfer Capability Definition and Determination, June 1996.

[5] H. Saadat, Power System Analysis, McGraw Hill, 1999.

[6] J.J Grainger, W.D. Stevenson, Power System Analysis, McGraw Hill, 1994

[7] Milano, Federico, "Continous Newton's Methode for Power Flow Analysis", IEEE Transaction On Power Systems, Vol. 24, No. 1, February 2009. pp. 50-57
[8] Milano, Federico, Power System Analisis Toolbox Documentation for PSAT Version 2.0.0, 2007. 